\title{
THEORETICAL VIEWPOINTS ON WOMEN'S SEGREGATION IN THE WORKPLACES
}

\author{
Muhammad Wayong \\ State Islamic University, Alauddin Makassar \\ Email: mwayong@gmail.com
}

\begin{abstract}
:
This paper depicts the vertical and horizontal segregation of women in the work places. It overviews the question of gender segregation both in developed and in the developing countries, particularly in the case of Indonesia. Female workers need bargaining power - their knowledge about working conditions and their skills to organize at work - in order to get well paid, high status jobs with good career opportunities. The low level of women's wage is assumed to be related to the levels of human capital such as education, training, and skill embodied in women.
\end{abstract}

Keywords: Segregation - Feminist - Workplace - Gender

\section{Introduction}

This paper offers an in depth analysis of the vertical and horizontal segregation of women in the workplace. It considers a number of theories related to gender segregation, particularly feminist perspectives with respect to women and work. The paper overviews the question of gender segregation both in developed and in the developing countries, particularly in the context of Indonesia. In addition, the question of why gender segregation in the workplace exists is analysed, as it may explain fundamental factors leading to gender inequality in the workplace. A number of theories, both classical and contemporary approaches, explaining 
this issue are presented. This includes Marxist theory, Patriarchal theory, Dual System theory, Dual Labour Market theory and Human Capital Theory ${ }^{1}$.

\section{Feminist Theory}

To start with, Marxist feminists investigate the specific nature of the oppression of women. They recognise that women are oppressed, and attribute their oppression to the capitalist system. Thus they insist that the way to end the oppression of women is to overthrow capitalism ${ }^{2}$. Unlike the liberal feminist view which identifies capitalism primarily as a system of voluntary exchange relations, Marxist feminists ${ }^{3}$ identify it as a system of exploitative power relations. Capitalism is described as a society in which every kind of transactional relation is fundamentally exploitative. The worker-employer relation, for example, can be

\footnotetext{
${ }^{1}$ These theories are selected based on their relevance to the issue, gender segregation in the workplace, addressed in this chapter.

2 According to Karl Marx, Capitalism is distinctive, in that it involves not merely the exchange of commodities, but the advancement of capital, in the form of money, with the purpose of generating profit through the purchase of commodities and their transformation into other commodities which can command a higher price, and thus yield a profit. In setting up conditions of production the capitalist purchases the worker's labour power - his ability to labour - for the day. Any work the worker does above this is known as surplus labour, producing surplus value for the capitalist. Surplus value, according to Marx, is the source of all profit. In Marx's analysis labour power is the only commodity which can produce more value than it is worth, and for this reason it is known as variable capital. Other commodities simply pass their value on to the finished commodities, but do not create any extra value. They are known as constant capital. Profit, then, is the result of the labour performed by the worker beyond that necessary to create the value of his or her wages [See Jonathan Wolff, Karl Marx, 2003, viewed 26 February 2007, < http://plato.stanford.edu/entries/marx $>$.

3 RP Tong, Feminist Thought: A More Comprehensive Introduction, ALLEN and UNWIN, Sydney, 1998, p. 96.
} 
looked at as a workplace struggle where the superior employer coerces workers to work ever harder for no discernible increase in wages.

In a similar vein, Alvesson and Billing claim that some Marxist feminists view capitalism as the foundation of all social inequalities, and the family as the root of women's subordination ${ }^{4}$. They assume that:

Capitalism is dependent upon the reproduction of the workforce, on a daily basis and over generations. The unpaid labour of women in the home served as a means to reproduce the primarily male labour force and thus the relations of production and capitalism. Because of this primary role of women, it is possible to pay them less when they had waged work - their labour is valued at a lower price than men's labour 5 .

Obviously, it is in the interests of capitalism to maintain a gendered division of labour in the family. All inequalities in society are advantageous to a capitalist system in that existing inequalities can be exploited to increase profits by paying different workers, different wages. Women's domestic activities in the home are regarded as non-productive or not real work and, therefore, they are rewarded less. In this way capitalist society further exploits female reproductive labour in the home in the reproduction of labour force. This is the reason that the gendered division of labour in the family is so vital for a capitalist system.

Marxist feminists view the description of the nature and function of women's work under capitalism as a trivialisation of women's work. They argue, in contrast to capitalism, that the value of any commodity produced for sale is determined by the amount of labour, or actual expenditure of human energy and intelligence,

\footnotetext{
${ }^{4} \mathrm{M}$ Alvesson, \& YD Billing, Understanding Gender and Organisations, SAGE, London, 1999, pp. 66-65.

5 Ibid., p. 65.
} 
necessary to produce $i t^{6}$. Based on this notion, they campaign for wages for housework, because they believe that:

Women gain a consciousness of themselves as a class of workers by insisting, for example, that domestic work be recognised as real work. That wives and mothers usually love the people for whom they work does not mean that cooking, cleaning, and childcare are not work ${ }^{7}$.

Similarly, Tong makes the assertion that women entering public service involves working a double day that begins with paid, recognised work and ends with unpaid, unrecognised work at home $^{8}$. The way to end this inequality, therefore, is for women to demand wages for housework. This might be a way for men to recognise the value of women's domestic work ${ }^{9}$. It is obvious that work roles in the capitalist system are gendered with women being progressively isolated in unpaid domestic work. This increases women's dependence on men, which further devalues female children to the point where families prefer to have male children to ensure better financial security. This will continue to make women subordinate to an identifiable breadwinner who is often male. This will further reduce the possibility of achieving equal opportunity in employment between the two genders.

Radical feminists, however, do not see capitalism as the fundamental source of women's oppression. Instead, it is the patriarchal system that oppresses women. Radical feminists claim that inequality between the two genders cannot be reduced to being an epiphenomenon of capitalism, rather, a more universal oppressive-patriarchal system. Although there are major controversies, most feminists agree that patriarchy refers to a

\footnotetext{
${ }^{6}$ RP Tong, op. cit. P. 96.

${ }^{7}$ Ibid., p. 98.

${ }^{8}$ Ibid., p. 108

${ }^{9}$ In the context of Buginese and Makassarese culture, men might argue that women should not claim their wages because, culturally, a good husband should offer all his salary to his wife to manage.
} 
system of social structures and practices, in which men dominate, oppress and exploit women ${ }^{10}$. Society is seen as a system of social relations between men who are dependent upon each other and who create solidarity. This makes it possible to control the labour of women and maintain the original division of labour between the genders, which is seen as the root of the present division of labour ${ }^{11}$.

Walby points out that the system of patriarchy comprises six main patriarchal structures. These are "a patriarchal mode of production; patriarchal relations within waged labour; the patriarchal state, male violence; patriarchal relations in sexuality; and patriarchal culture"12. The first two of these are patriarchal structures regarding gender segregation in the workplace, which is the focus of this section. The patriarchal mode of production is a patriarchal structure operating at the economic level, which refers to a situation in which a husband within the marriage and household relationship expropriates women's labour. The work performed by housewives for their husbands and family that may range from cooking, cleaning to caring for their children and elderly relatives is not financially rewarded with money and therefore is seen as having less value than paid work. In a similar vein, patriarchal relations in paid work exclude women from paid work or segregate them within it. Walby describes the patriarchal structure as:

A complex of forms of patriarchal closure within waged labour exclude women from the better forms of work and segregate them into the worse jobs which are deemed to be less skilled ${ }^{13}$. 1989 , p. 214.

10 S Walby, 'Theorizing Patriarchy', Sociology, Volume 23, No. 2,

${ }^{11}$ M Alvesson, \& YD Billing, op.cit., p. 66.

12 Ibid., p. 220.

${ }^{13} \mathrm{~S}$ Walby, Theorizing Patriarchy, Basil Blackwell, Oxford, 1990, p.21. 
This structure, obviously, results in the devaluation of women's work and low wages for them, which does not only affect women's paid work, but also work in other areas, including the domestic sphere and other aspects of gender relations. Within the sphere of paid work, occupational segregation is the most important concrete aspect of patriarchal relations in industrialised countries today, which may be in the form of either or both vertical and horizontal gender segregation, and between full timers and part timers. The Marxist and Radical feminist viewpoints, as discussed above, have been synthesised by Hartmann as having equal standing, which is described in the Dual System theory.

Under the Dual System approach, Hartmann views patriarchy and capitalism as in harmony in each other ${ }^{14}$. The present division of labour is regarded as a result of a long process of interaction between patriarchy and capitalism and is fundamental for the reproduction of patriarchy. Capitalism and patriarchy constitute two analytically distinct systems of power relations, which meet and interact and empirically work together, encouraging gender antagonisms and systematically oppressing women, respectively. Not just capital but also men's actions [patriarchy] are believed to reproduce gender segregation in the workplace. This also commented in by Rogers who points out:

The new division of labour, which identifies women with the domestic sphere and men with the "outside world" of the modern economy, is both cause and effect of the virtual monopoly by men of the important positions in the socio-economic hierarchy, and their associated control of the main institutions of modern society: law, politics, public administration, male clubs, the armed forces and police, commerce, industry and banking, trade unions, the media and other major institutions ${ }^{15}$.

\footnotetext{
${ }^{14}$ See M Alvesson, \& YD Billing, op.cit., p. 67.

15 B Rogers, The Domestication of Women, Tavistock Publication, London, 1980, p. 25.
} 
This gender division of labour is often justified by reference to biological argument, which implies that women ought to prioritise domestic duties and child rearing. The basis of this argument is not only fraught with problems, it also reduces women's intellectual ability on the basis of their biology. While the so-called natural laws of human biology have been presented as the ultimate justification for inequality between men and women, gender divisions in society are socially constructed.

In relation to this, Hartmann also ascertains that men benefit from job segregation in two ways. Firstly, male workers are able to take the best-paid jobs because they are better organised than women ${ }^{16}$. Also, men have access to sources of power to support their claim, because they control the state ${ }^{17}$. Capital, as well as patriarchy, benefits from job segregation, because it enables employers to pay women low wages since there is an oversupply of women for the few remaining jobs ${ }^{18}$. Additionally, the system locks into a vicious circle in which women have even less access to the acquisition of the skills and experience necessary for the better jobs because of their work as housewives.

16 This statement might be no longer relevant. Since women form a majority of students in tertiary education and improve their human capital, many of them enter the best-paid job and prove to be successful workers. The idea that men are better organised than women in work is a cultural preconception.

17 See S Walby, Gender Segregation at Work, Open University Press, Philadelphia, 1988, p. 22.

18 Women's career options are limited to certain professions because of cultural reasons prescribed by society. They are stereotyped with culturally considered feminine subjects while men do not have such restriction. This allows men to enter any type of works, while women do not. In fact, women are continuously under represented in work considered beyond their realm, such as engineering. 


\section{Women's Segregation In The Workplaces}

The social construction of female roles in society do not emanate from their biology. Indeed, cultural preconceptions degrade women's position in employment particularly when we come to the point of thinking of certain jobs as typically male or female, such as taking care of children or mining and becoming a secretary or a manager of a company. These perceptions reflect the gendering of work roles, that is, they reflect a social and cultural definition of who should do what, and are not inevitable, 'natural' roles emanating from our biology. Instead, this gendering occurs for economic and political reasons, and in turn, the process of gendering reflects male power in society [patriarchy]. Female subordination becomes inevitable and natural because of women's biological make up and is a result of patriarchal ideology.

Walby further argues that Hartmann's approach of job segregation by gender was a critical advance in theorizing gender relations in employment. In spite of this, Walby is doubtful whether or not Hartmann is able to sustain an analytic separation between the two systems. Additionally, her analysis is too general to account for the variations in the extent and forms of occupational segregation that exist. Moreover, Walby argues, her analysis of the relations between patriarchy and capitalism overstates the degree of harmony between the two systems $^{19}$.

Barron and Norris ${ }^{20}$ in their work with Dual-Labour Market theory divide the labour market into two separate sectors - the primary and secondary sector. The former is characterised by well paid, high status jobs with good career opportunities; whereas the latter is characterised by dead-end, low paid jobs, with bad working conditions, tight supervision

${ }^{19} \mathrm{~S}$ Walby, op.cit., pp.22-23

20 RD Barron \& GM Norris, 'Sexual Divisions and the Dual Labour Market', in DL Barker \& S Allen [eds.], Dependence and Exploitation in Work and Marriage, Longman, London, pp.48-52. 
and little chance of promotion. An important question to address here is why male workers tend to occupy the higher rungs of a chosen occupation, whereas female workers are left firmly at the bottom of the hierarchy. In this respect, Barron and Norris point out that worker stability is of great importance for the primary sector jobs. With regard to their reproductive role, women's careers seem to be continually interrupted. Men do not encounter these issues. Moreover, this disruption impacts on the way in which they are regarded by employers. Thus, even with equal qualifications, men are more likely to obtain greater chances of progress in terms of wages, training and promotion. Due to this, female workers are more likely to be relegated to the secondary jobs category ${ }^{21}$ and their position will, particularly, be set aside when the labour market is structured according to capitalist requirements.

Another possible reason that women tend to be in low-wage, dead-end jobs is their lack of access to other spheres of employment which would enhance the opportunities. Indeed, the labour market itself operates in accordance with non-gendered principles. However, it has been increasingly clear that gender or power relations between men and women permeates all social institutions and that the supposedly objective economic laws of market competition work through and within gendered structures. The labour market operates not only to exclude women from skilled jobs, but also to down-grade jobs when they are performed by women.

Ironically, occupational segregation by gender does not only occur in capitalist countries; instead, it is an international issue, as it takes place globally both in developed and in developing countries. Nevertheless, this is a substantive issue and of much concern in developing countries. In Indonesia, for example, male workers dominate the primary job sectors in professions such as doctors, lawyers, lecturers, politicians, and top echelons of government; while female workers are predominantly in secondary sector jobs such as teaching at kindergarten and primary school, nursing, the

${ }^{21}$ Ibid., pp. 54-64. 
service industry and manual workers in manufacturing ${ }^{22}$. However, there is an indication that Indonesian women are gradually moving into the primary job categories. This might be due to the success of government in increasing the level of female education and the success of the family planning program $^{23}$, which encourages the community to focus on having small families. Additionally, it is assumed that there are some secondary sector jobs, which are the domain of female workers, that are eventually classified as primary sector employment, particularly when the jobs become more competitive as they offer good pay and require skilled and academically qualified workers. In this respect, nursing, teaching at secondary schools and clerical work are relevant examples.

This approach seems to be reasonable in explaining women's position in the labour market and helps to explain the occupational distribution of men and women, as it provides an understanding of gender inequality. Nevertheless, it has been subjected to some criticism. This theory does not explain the gender segregation which occurs within the secondary and primary sectors and the reason why gender is such a persistent and important dimension for labour market segmentation. This approach should not classify female employment into the single

${ }^{22} \mathrm{JB}$ reeves, Work and Family Roles: Contemporary Women in Indonesia', Sociological Spectrum, Volume 7, 1987, p.230.

${ }^{23}$ In Indonesia, the total fertility rate declined from 5.6 children per family in 1967-70 to 2.85 children in 1994. Dramatic increases in contraceptive use, spurred by economic growth and the government of Indonesia's family planning program, are credited for this decline. Indonesia's family planning program promotes smaller families as a means to improve family welfare. The government supports the concept of The Happy and Prosperous Family, defined as a family based on "legal marriage, capable of adequately fulfilling spiritual and material needs, devoted to God, possessing harmonious, proportionate, and balanced relations among its members and between the family, society, and the environment. [See Indonesia: Family Planning, Family Welfare and Women's Activities, viewed 5 March 2007, <http://www.fhi.org/en/RH/Pubs/ wsp/fctshts/Indonesia1.htm>. 
unified category of secondary sector work ${ }^{24}$. The reason for this is that this approach does not apply universally to all jobs, for example, it might be appropriate to manual manufacturing, but not to clerical work ${ }^{25}$.

Finally, this section considers Human Capital Theory as another approach to understand gender segregation in the workplace. This theory assumes that people act as a consequence of rational calculations of economic benefit. In other words, workers choose paid work proportionate to their human capital ${ }^{26}$. Mincer, a human-capital theorist, views gender differences as a consequence of women's commitment to the domestic sphere. He argues that women choose between paid work, housework and leisure under market conditions, that is, housework is work with a value like any other form of work. Women's participation in paid employment is 'flexible' due to the alternative forms of work, which is open to them in the household ${ }^{27}$. It is the availability of these alternative forms of productive activity, which is seen by Mincer to be the explanation of married women spending only part of their time in paid work.

Mincer's 1966 study explains the position of women in paid work in terms of their lesser human capital. He argues that women have acquired fewer skills and qualifications and less labour market experience than men have. This is because of the domestic division of labour in which women spend more time than men looking after children and performing other

${ }^{24} \mathrm{~V}$ Beechey \& $\mathrm{T}$ Perkins, A Matter of Hours, University of Minnesota, Minneapolis, 1987, pp.137-138.

${ }^{25} \mathrm{~S}$ Walby, Patriarchy at Work: Patriarchal and Capitalist Relations in Employment, Polity Press, Cambridge, 1986, p.82.

${ }^{26}$ S Walby, op.cit., pp. 15-16.

${ }^{27}$ See S Walby, Patriarchy at Work: Patriarchal and Capitalist Relations in Employment, Polity Press, Cambridge, 1986, pp. 71-72. 
household tasks ${ }^{28}$. Along with this, Polachek's 1981 study pointed out that women with less human capital chose those occupations for which their lesser skills gave the best rewards, and in which they were least penalised for their intermittent work pattern ${ }^{29}$. Similarly, Aldred, Ellis, and Beale [cited in Munro] make the point that women tend to work in smallscattered workplaces, where it is generally more difficult to organise. Women in small work groups have close daily contact with the management, which may make this work environment uncomfortable and difficult. Due to the nature of their jobs, many of them are employed in small work groups even where the employing organisation is large ${ }^{30}$.

\section{Conclusion}

To conclude, female workers need bargaining power their knowledge about working conditions and their skills to organise at work - in order to get well paid, high status jobs with good career opportunities. The low level of women's wage is assumed to be related to the levels of human capital such as education, training, and skill embodied in women ${ }^{31}$. This

28 Mincer's work may not be as relevant in the $21^{\text {st }}$ century since more women today with greater resource of human capital form the majority of students in universities.

${ }^{29}$ See S Walby 1988, op.cit., p.15.

${ }^{30}$ A Munro, Women, Work and Trade Unions: Employment and Work Relations in Context Series, Mansell, London, 1999, p.13.

31 These theories are selected based on their relevance to the issue, gender segregation in the workplace, addressed in this chapter. 
statement clearly assumes that gender segregation should decline as women's possession of human capital rises towards that of men. The decrease in the gap in the educational qualification of boys and girls and the decrease in the number of years women take out of the labour market to have children may redress gender balance in terms of pay and career promotion. However, we now have women with greater resources of human capital. They form the majority of students in Universities but still women maintain an inferior position to men in the labour market. This is the contemporary situation that has to be

\section{DAFTAR PUSTAKA}

Billing, M Alvesson, \& YD, Understanding Gender and Organisations, London : SAGE, , 1999.

Munro, A, Women, Work and Trade Unions: Employment and Work Relations in Context Series, London Mansell, , 1999.

Perkins, V Beechey \& T, A Matter of Hours, Minneapolis: University of Minnesota, , 1987.

Rogers, B, The Domestication of Women, London: Tavistock Publication, , 1980.

Tong, RP, Feminist Thought: A More Comprehensive Introduction, Sydney: ALLEN and UNWIN, 1998.

Walby, S, Gender Segregation at Work, Philadelphia: Open University Press, , 1988.

Walby, S, Patriarchy at Work: Patriarchal and Capitalist Relations in Employment, , Cambridge: Polity Press, 1986.

Walby, S, Theorizing Patriarchy, Oxford : Basil Blackwell, , 1990.

Walby, S, 'Theorizing Patriarchy', Sociology, Volume 23, No. 2, 1989.

JICSA Volume 05- Number 02, December 2016 
addressed. The question of whether gender bias is a cause of differences in pay and career promotion is important, persistent and still unresolved. 